\title{
JUURNAL.RU
}

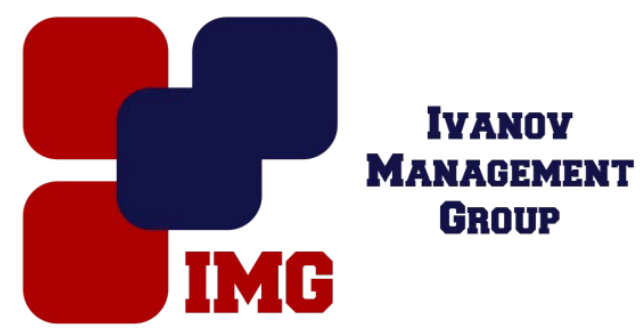

Манулин В.Ю.

doi: 10.18411/lj-30-11-2016-4-08

idsp 000001:lj-30-11-2016-4-08

\section{Судопроизводство в русском государстве XVII в.}

\section{Аннотация}

Автор раскрывает особенности правового регулирования сферы судопроизводства в Русском государстве ХУ11 в. Подробно анализируются нормы Соборного уложения 1649 г. и других актов, принятых в рассматриваемый период, по различным аспектам процессуального права. Делаются соответствующие обобщения.

Ключевые слова: судопроизводство, процессуальное право, судоустройство, Соборное уложение, апелляция, третейский суд.

В ХУ11 в. в России уголовный процесс еще не отделяется от гражданского. После издания Судебника 1550 г. и до принятия Соборного уложения 1649 г. нормативная база процессуального характера пополнялась разного рода указами и узаконениями, при том, однако, что каких-либо принципиальных изменений не происходило - законодатель больше внимания уделял отдельным вопросам судопроизводства. Наиболее подробно и в обобщенном виде эти вопросы нашли отражение в Соборном уложении 1649 г. Здесь следует выделить прежде всего Главу X - «О суде» и Главу ХУ - «О вершенных делах и о третейском суде».

Обращает на себя внимание то обстоятельство, что название Гл. X не совсем соответствует ее содержанию, поскольку в ней отражены не только вопросы судопроизводства и отчасти судоустройства, но и в значительном объеме вопросы процессуального и материального права и в целом такое внимание говорит о контроле со стороны государства о финансовых потоках в стране [1]. В этой связи В. И. Сергеевич следующим образом связывал последовательность статей главы с судебником: «Подобно судебникам, она начинается с перечисления лиц, которым принадлежит суд, затем идут статьи о порядке суда, о вызове, о явке на суд и т. п. процессуальные постановления. Потом следуют статьи о преступлениях, а в конце находим постановления, касающиеся гражданского права» [2, с. 607]. При этом, по справедливому 
замечанию Ф. Дмитриева «все гражданские дела начали склоняться к следственному процессу» [3, с. 379]. Это очень важное положение. Дело в том, что в период судебников в гражданском судопроизводстве уже наблюдалось усиление публичных начал [4].

В период Уложения этот процесс продолжался, что, в свою очередь, отражало тенденцию становления в России абсолютистского режима. При этом следует особо подчеркнуть, что Уложение содержит регламентацию делопроизводства только в отношении дел, рассматриваемых судебным или обвинительным процессом, то есть тем процессом, которым охватываются состязательная форма судопроизводства. Это вытекает не только из того, что статья помещена в главе «О суде», но главным образом из того, что в самой статье речь идет о «судных делах в приказах». Регламентации делопроизводства по делам о татьбе, разбое и г. п., решаемым в порядке розыскного процесса, уложение не содержит (регламентируется только стадии следствия - допрос, очная ставка, повальный обыск, пытка - Гл. XXI). И это не случайно. Дело в том, что гражданские дела, рассматриваемые судом, не исключали возможности апелляции в вышестоящую инстанцию, а потому делопроизводство должно было вестись со всей строгостью «впредь до спору». В уголовных же делах апелляция, как правило, исключалась (хотя известны челобитные татей и разбойников, заключенных в тюрьмы, с жалобами на воевод, но их нельзя приравнивать к апелляции - это произойдет значительно позже, в X1X в. [5, с. 186]). Однако именно в отношении гражданско-правовых споров законодатель счел нужным достаточно подробно отрегулировать требования к процессуальным документам и порядку их утверждения. Это свидетельствует о важности предмета судебного рассмотрения, связанного с имущественными отношениями.

В ст. 122 Главы X данное положение находит развитие: «А будет и порутчики съедут, и на них или на их людех и крестьянех те государевы пошлины велеть доправити в городех, где кто живет, а для правежу тех денег послати с Москвы недельщика, а езд недельщику велеть доправити на них же, или на людех их и на крестьянех, кто будет в лицах». Это важная для нас норма, поскольку в практике разрешения гражданских споров она применялась достаточно активно [6, с. 50]. Уложение 1649 г. законодательно закрепило существующую практику. Мировая сделка могла быть заключена до обращения сторон в суд, после обращения в суд (но до судоговорения) и, наконец, в ходе судоговорения, но до вынесения решения. Если она состоялась вне суда, то истец и ответчик были обязаны подать судьям мировые челобитные и платить пошлины. Примирение сторон в ходе судоговорения влекло подачу полюбовной сказки, которую дьяк скреплял, предъявлял судьям и прилагал к делу.

Примирение касалось лишь гражданского процесса - уже тогда оно не допускалось по делам о кражах, разбоях, убийствах, что свидетельствует о том, что государственное начало проникало в судебный процесс все же дифференцированно. Государство, в частности, как видно из вышеприведенных 
норм, пытается вводить такие правила, которые обеспечивали бы более быстрое и справедливое решение.

Ряд норм, регулирующих рассмотрение гражданско-правовых дел, содержится в Гл.ХУ Соборного уложения - «О вершеных делах и о третейских судах». Наличие третейские суда также свидетельствуют о развитии состязательного начала в процессе. Следует заметить, что это первый общий закон о третейском суде [7, с. 43]. В ст. 5. регламентируется порядок судопроизводства в третейском суде, который состоял из третьих лиц, выбранных по обоюдному соглашению тяжущихся сторон. Заметим, что третейский суд уходит корнями в обычное право [8] (например, суд братчины в Новгороде), и в России он имел место до Уложения 1649 г. и после него. Ученые монархического периода России рассматривали третейский суд как свободный гражданский договор [9]. Имеется и иная точка зрения - например, А.Г. Маньков полагает, что это не так, поскольку сам суд санкционирован законом (во всяком случае с Уложения) и условия, на которых о должен функционировать, также установлены им [10, с. 251]. Нам представляется, что такое противопоставление не имеет оснований, поскольку абсолютно свободного договора в имущественных спорах не может быть в принципе - в любом случае он имеет более или менее детальную нормативно-правовую регламентацию; вместе с тем сам договор (причем любой) по своей сути не может быть не свободным, в противном случае это не будет договором. Наличие же самого третейского суда свидетельствует о наличии профессиональных юристов [11].

Важно констатировать, что принципы третейского суда по своей сути в дальнейшем не изменялись. Как видно, Соборное уложение достаточно основательно регулировало вопросы процессуального разбирательства гражданско-правовых споров, определив правовую базу в этой сфере социальных отношений на достаточно длительное время, при этом предмет спора касался в абсолютном большинстве случаев имущественных отношений [12]. Это не значит, что не было уголовного судопроизводства - он, разумеется, имел место [13], другое дело, что этот процесс не находил достаточного отражения в законах, но, тем не менее, институт объекта преступлений тогда уже имел по сути такое понимание, как и сейчас [14, с. 40] (равным образом это касается и развития материального уголовного права [15]).

В дальнейшем, после Соборного уложения, законодатель регулировал отдельные вопросы гражданского судопроизводства. В частности, по самой процедуре судебного делопроизводство законодатель предъявлял все большие требования к формализации судопроизводства. Чаще всего основанием решения служило прежде всего признание. Оно с давних пор имело решающее значение в процессе и приводило к его прекращению. Признание погашало действие иска. Если оно было частичным, то иск погашался также частично. Остальное рассматривалось в судебном порядке. Такое положение было подтверждено указом 1678 г. Кроме того, признание, сделанное перед присягой, снимало ее 
необходимость [16]. Судебное делопроизводство приказов было составной частью общего приказного делопроизводства.

Заметным явлением в судебном деле было издание 11 ноября 1685г. Судных статей о порядке судопроизводства и о взыскании проестей и волокит. Здесь законодатель довольно строго регулирует последствия нарушения надлежаще установленного срока явки в суд - нарушитель проигрывал дело, кроме того, вводились санкции за волокиту дела со стороны истца и ответчика. Указом от 26 мая 1692 г. было дано разъяснение в том, как считать месячный срок для явки в суд - было предписано, что все месяцы в году считать по 30 дней, а начинать 30 дней с того числа, когда приставная память или поручная запись будет подписана дьяком и записана в книгу [13, с. 596]. Таким образом, бюрократизация проникала и в сферу судопроизводства, что, на наш взгляд, на том этапе развития суда в России следует расценивать положительно, поскольку способствовало укреплению законности.

Таким образом, с середины ХУ11 в. наблюдается повышенная активность государства в издании правовых актов, регулирующих гражданскопроцессуальные отношения, что нашло отражение в нормах Соборного уложения (1649 г.), Новоторгового устава $(1667$ г.) и других документах. Увеличивался и объем рассматриваемых судами исков. В Соборном уложении законодатель систематизирует нормы о судопроизводстве. Упорядочивается система судов, хотя в ней по-прежнему остается трехзвенная структура, однако наблюдается существенное изменение - если ранее низший суд осуществляли в значительной части выборные люди, что в ХУ11 в. это делает уже государевы люди в приказах и на местах (воеводы). В целом этот и другие факты свидетельствуют о том, что в судопроизводственном процессе по гражданским делам все большее значение приобретает государственное начало. Вместе с тем законодатель в Уложении особо выделяет третейский суд именно для категории прежде всего имущественных споров, что соответствовало европейской практике [17] (чего не скажешь о других сферах, например, в тюремной сфере [18]). Во второй половине ХУ11 в. осуществляется дальнейшая бюрократизация суда, что на том этапе развитие судопроизводственного процесса еще имело прогрессивный характер, так как устраняло пробелы, которыми пользовались недобросовестные участники судебных процессов. 


\section{Литература}

1. У Уоров И.В., Старков О.В. Финансовое право. Москва, 2013.

2. Сергеевич В.И. Лекции и исследования по истории русского права. СПб., 1883.

3. Дмитриев Ф. История судебных инстанций и гражданского апелляционного судопроизводства от Судебника до учреждения о губерниях. М., 1859.

4. Старков О.В., Упоров И.В. Теория государства и права / Под общ. ред. О.В. Старкова. Москва, 2012.

5. Рассказов Л.П., Упоров И.В. Тюремные инструкции в Российской империи / Под ред. В.И. Лысенко. Краснодар, 1999.

6. Веселовский С.Б. К вопросу о происхождении вотчинного режима. М., 1926.

7. Вицин А. Третейский суд по русскому праву. М., 1858.

8. Конституционное (государственное) право России: учебник для студентов высших учебных заведений, обучающихся по специальности "Юриспруденция" / Смоленский М. Б., Упоров И. В., Звягольский А. Ю. Москва, 2009.

9. Кавелин К.Д. Собрание соч. Т.4. СПб., 1904. С. 235; Дмитриев Ф. История судебных инстанций и гражданского апелляционного судопроизводства от Судебника до учреждения о губерниях. М., 1859.

10. Маньков А.Г. / Комментарий к Гл. Х Соборного уложения // Соборное уложение 1649 года. Л.: Наука, 1987.

11. Старков О.В. Упоров И.В. Юриспруденция. Введение в специальность. Москва, 2005.

12. Упоров И.В. Преступное имущественное насилие: понятие, уголовноправовое регулирование и предупреждение. Москва, 2015.

13. Беляев И.Д. История русского законодательства. СПб., 1999.

14. Упоров И., Хун А. Объект уголовно-правовых отношений: содержание и различие со сходными понятиями // Уголовное право. 2003. № 4. С. 40.

15. Агафонов Ю.А., Упоров И.В. Историческое развитие уголовного права России. Москва, 2003.

16. ПСЗ. II. № 741,742 .

17. Грошев А.В., Упоров И.В. Уголовное право России. Общая часть. Краткий учебный курс. Ростов-на-Дону, 2006.

18. Упоров И.В. Правовое регулирование естественных прав человека в местах лишения свободы / Под редакцией М.П. Мелентьева. Рязань, 1998. 